\title{
Damping-off of sugar beet in Finland I. Causal agents and some factors affecting the disease
}

\author{
MAURITZ VESTBERG*, RISTO TAHVONEN*, KYÖSTI RAININKO ${ }^{* *}$ and NILS \\ NUORMALA
}

"Department of Plant Pathology, University of Helsinki, SF-00710 Helsinki 71, Finland $*$ Sugar beet Research Centre, SF-25170 Kotalato, Finland

\begin{abstract}
The fungus Pythium debaryanum auct. non Hesse is the main cause of damping-off on sugar beet in Finland. The fungus is found especially in diseased seedlings during the first two weeks after emergence. Later on, when the plants have one or two pairs of true leaves, Fusarium spp. can be isolated to a rather great extent. However, pathogenicity tests with three different Fusarium species have shown that this fungus is unble to cause damping-off on sugar beet when inoculated into peat substrate. Among the fungi tried in this respect, only Pythium debaryanum and Phoma betae Frank showed clear pathogenicity. Sugar beet seedlings that outlive the disease grow slower, and their quality at harvest in the autumn is poorer than that of healthy beets.
\end{abstract}

\section{Introduction}

The damping-off of sugar beet is caused by seed borne and also by soil borne fungi. Among the seed borne damping-off pathogens Phoma betae Frank is the most important (NÖLLE 1960). The degree of $P$. betae infection in the seed varies considerably depending on the origin of the seed. According to LEACH (1941), the European sugar beet seeds are mainly contaminated with $P$. betae, while in some cases seeds from the U.S.A. have proved to be clean from infection. Polygerm seeds have proved to be more heavily infested with $P$. betae than monogerm seeds (SCHULTZE and BOHLE 1976).

Among the soil borne fungi causing damping-off of sugar beet, species of the genus Pythium Pringsh. are the most widely distributed (BUCHHOLTZ 1938, NÖLLE 1960, PESHEL 1969, KÜHNEL 1978). Within the genus, the species $P$. debaryanum Hesse, $P$. ultimum Trow and $P$. aphanidermatum (Edson) Fizp. have often been isolated (BUCHHOLTZ 1938, HILLS and LEACH 1952, GATES and HULL 1954, TILL 1968, LINNASALMI 1970, BÖTTCHER and BEHR 1980). Species of Aphanomyces de Bary give rise to damping-off on sugar beet in Europe and America. In Europe, A. laevis de Bary (GREIS 1942) seems to be somewhat common and in the western hemisphere A. cochlioides Drechs. (BUCHHOLTZ 1938, COONS et al. 1948, 
PAPAVIZAS and AYERS 1976). Rhizoctonia solani Kühn has also been isolated as a damping-off pathogen of sugar beet but has not been found to be as important as for instance $P$. debaryanum (COONS and STEWART 1927, HILLS and LEACH 1952). Another organism, Fusarium spp., has commonly been found in investigations concerning the damping-off disease of sugar beet, but the actual importance of this fungus is controversial. According to HODGES (1936), MÖLLERSTRÖM and KLINTEBERG (1964) and BÖTTCHER and BEHR (1980) Fusarium species can be considered as primary pathogens on sugar beet seedlings although contradictory opinions are also existing (GATES and HULL 1954, LINNASALMI 1970, KÜHNEL 1978).

Damping-off investigations from Northern countries are only available by few research-workers, among others BJÖRLING (1945), MÖLLERSTRÖM and KLINTEBERG (1964), RASMUSSEN (1967), LINNASALMI (1970) and MÖLLERSTRÖM (1974). In Finland there have been severe outbreaks of damping-off on sugar beet in certain areas during the last few years, thus there has been need for a more profound investigation into the causes.

The aim of this study is to survey the most common causal agents of damping-off on sugar beet in Finland and also to study some factors affecting the disease. The investigations have been carried out in co-operation with the Finnish Sugar Beet Research Centre.

\section{Materials and methods}

\section{Introductory experiments}

Introductory experiments on the damping-off disease of sugar beet were started in the late autumn of 1978. Soil samples were collected from 48 sugar beet fields where damping-off occurred (Fig. 1). One half of each soil sample was sent to the Sugar Beet Research Centre, where the soil type, $\mathrm{pH}$ number and the content of humus, clay and phosphorus, potassium, sodium and magnesium were determined in the laboratory. The other half of each soil sample was examined, from a plant pathological point of view at the Department of Plant Pathology, University of Helsinki. The bait method was used to determine the degree of soil infection. The experiment was carried out at high $\left(+18-+20^{\circ} \mathrm{C}\right)$ and low $\left(+8-+10^{\circ} \mathrm{C}\right)$ temperatures in a greenhouse. Untreated Monohill sugar beet seeds were used. Under the course of the experiment, healthy and diseased seedlings were counted at emergence and at about one 1 week intervals after emergence. Seedlings with damping-off symptoms were removed from the pots and the causal agents of the disease were determined in a laboratory.

\section{Field experiments}

Disease control experiments have been carried out during 1979-1981 in co-operation with the Sugar Beet Research Centre. The localities of these 


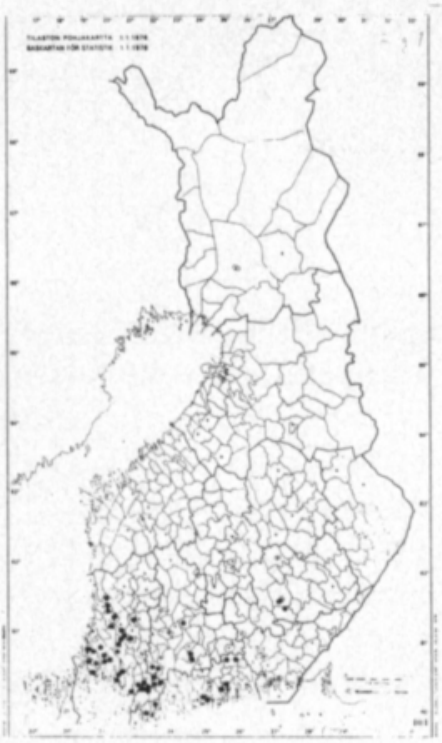

Fig. 1. The localities of soil samples.

Fig. 2. The localities of field experiments, from which diseased sugar beet seedling samples were collected for determination of the causal agents of damping-off during 1979-1981.

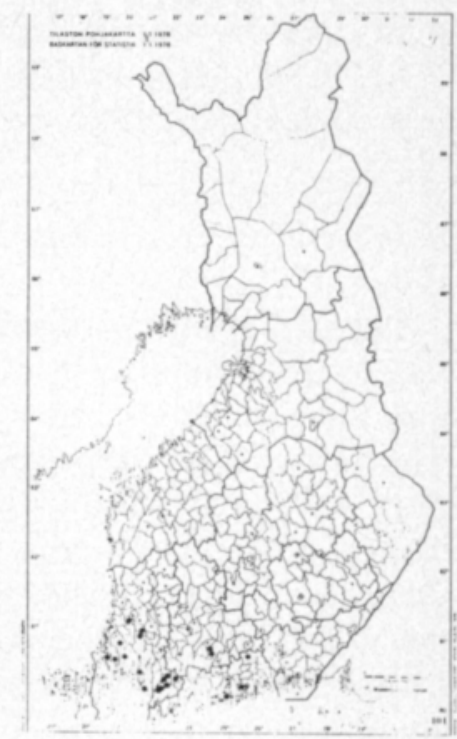

experiments were chosen according to the degree of disease found in the soil sample investigation (Fig. 2) and only the most severely diseased fields were chosen. All trials except those at Viikki Experimental Farm and at Pohjankartano Sugar Beet Experimental Farm were on fields of sugar beet growers. The sugar beets in the experimental areas were cultivated using the same techniques and fertilization levels as the farmer.

Seedlings with visible signs of damping-off were collected from all localities 10 days and 20 days after emergence. The samples were taken to the Department of Plant Pathology where the causal agents of the disease were determined.

The differences in the quantative and qualitative development between healthy and diseased, but living plants was studied on two localities in 1979 (Helsinki and Porvoo) and on five localities in 1980 (Helsinki, Janakkala, Salo, Mietoinen and Köyliö). After singling, 120 plants with disease symptoms were marked on all localities. In the middle of July and August and at the end of September, 40 diseased plants and 40 healthy plants from the areas between the diseased ones were taken for the determination of root- and topweight. At the end of September, the sugar content and the content of amino- $\mathrm{N}$, potassium and sodium were also determined at the Sugar Beet Research Centre.

\section{The isolation and identification of damping-off fungi}

The causal agents of the disease were determined by putting pieces of diseased plant parts on agar into petri dishes $(\varnothing 9 \mathrm{~cm})$. The samples were first carefully rinsed under running water. Thereafter they were surface sterilized for $1 \mathrm{~min}$. in $1 \% \mathrm{NaOCl}$ and after that for some seconds in $94 \%$ ethanol. When the samplses had dried they were put on corn meal agar with 100-300 
ppm streptomycinsulphate. The dishes were kept at room temperature $(+20$ $-+24^{\circ} \mathrm{C}$ ) and examination of the fungi with a stereo- and a lightmicroscope was started after about two weeks.

\section{Pathogenicity experiments}

The pathogenicity of some fungi isolated from sugar beet plants in 1980 was tested in autumn of the same year. The test organisms were inoculated into light colour peat moss 1 week before the sugar beet seeds were sown. The basic fungus suspensions that were inoculated into pots with $1.5 \mathrm{l}$ of peat, were prepared by homogenicating the mycelium of 1 petri dish $(\varnothing 9$ $\mathrm{cm}$ ) into $100 \mathrm{ml}$ of sterile water. Dilutions were then made from this basic suspension. The seed used was untreated naked Monohill. Observations were made just after emergence and thereafter during one week intervals. The pathogenicity tests were carried out in a greenhouse with a temperature of about $+18-+20^{\circ} \mathrm{C}$.

\section{Weather conditions}

There were considerable annual variations in the weather during May and June 1979-1981. May was in 1979, and especially in 1981 warmer than normal. However, in 1980 especially at the end of the month May was very cool (Fig. 3). June was cooler than normal in 1981 with some very heavy rainfalls. During 1979 and 1980 the precipitation was somewhat normal in June and the same applies for May during all three years.

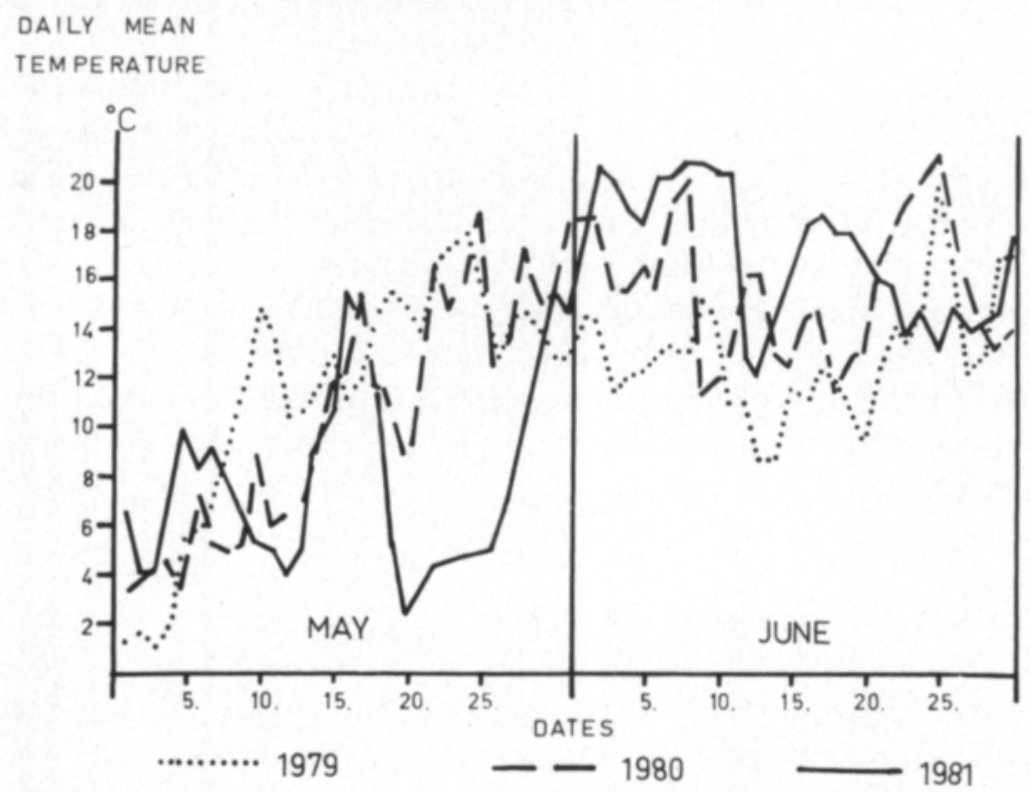

Fig. 3. Daily mean temperatures in May and June 1979-1981. Averages from the following observation statios: Helsinki Kaisaniemi, Hattula Leteensuo, Turku Airport and Kokemäki Peipohja. 


\section{Results}

\section{Disease symptoms}

In this investigation the main importance has been attached to postemergence damping-off symptoms, although pre-emergence damping-off appeared in some cases.

Beet seedlings are usually healthy at the time of emergence, the first disease symptoms not appearing until $1-1 \frac{1}{2}$ weeks later. Infection at this stage usually leads to complete wilting and rapid death of the plant. A watersoaked, brown to grey or black area extends up and down the hypocotyl or the upper portion of the young taproot from the point of entry of the pathogenic organism. Discoloration may also, in later stages extend up into the petioles of the cotyledons. The collapse of the hypocotyl of the seedling is followed by desiccation. Under favourable conditions the following development may take place within 1-2 days (Fig. 4).

When sugar beet seedlings with 1-2 pairs of true leaves are attacked by damping-off pathogens they usually survive for several days after the initial symptoms appear (Fig. 5). Often such diseased plants recover and persist through the growing season. However, they have a slower growth than healthy plants and their neck collar is weak and typically "strangled" thus, later in the summer they easily break at the root collar due to strong winds or

Fig. 4. Damping-off in sugar beet at the cotyledon stage. The healthy seedlings in the lower row.

Fig. 5. Damping-off in sugar beet with 1-2 pair of true leaves. Two healthy seedlings on the left.
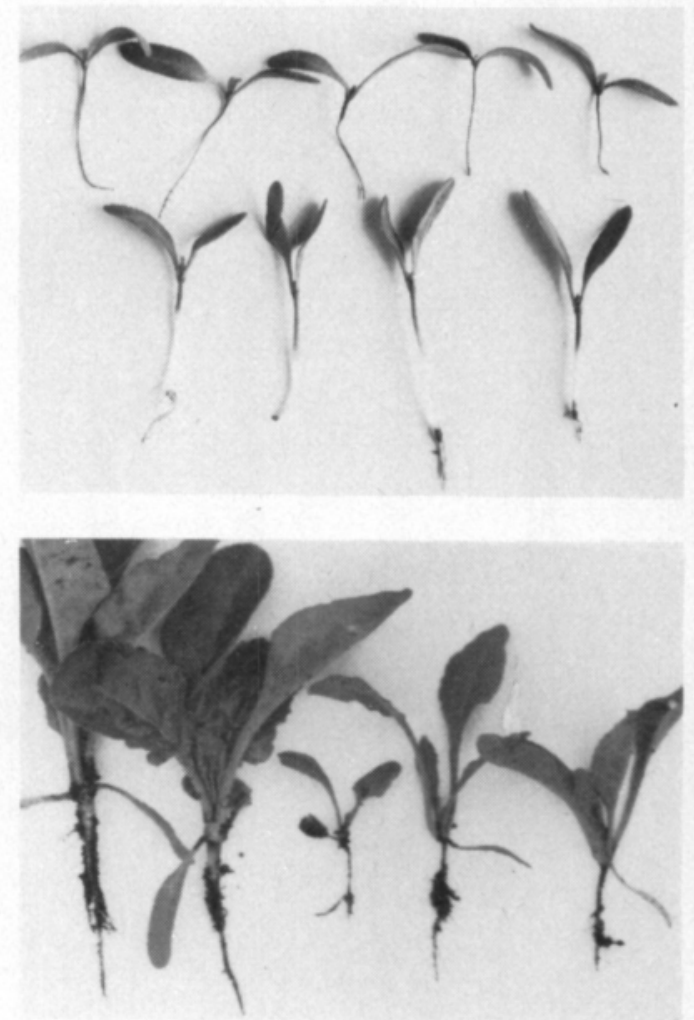


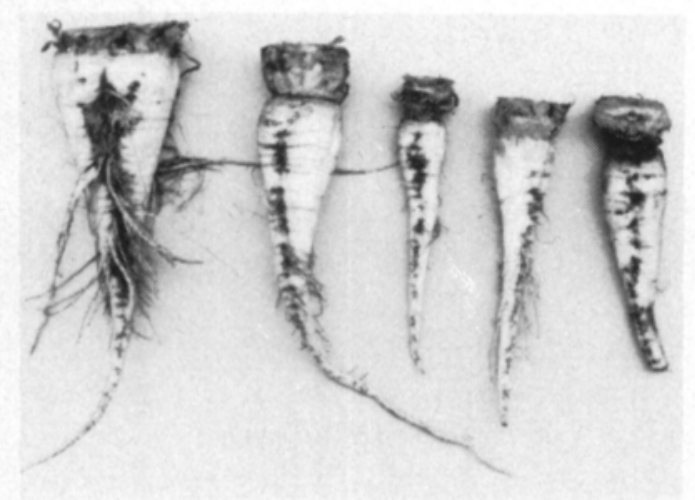

Fig. 6. Beets with strangled neck collar. Healthy beet to the left.

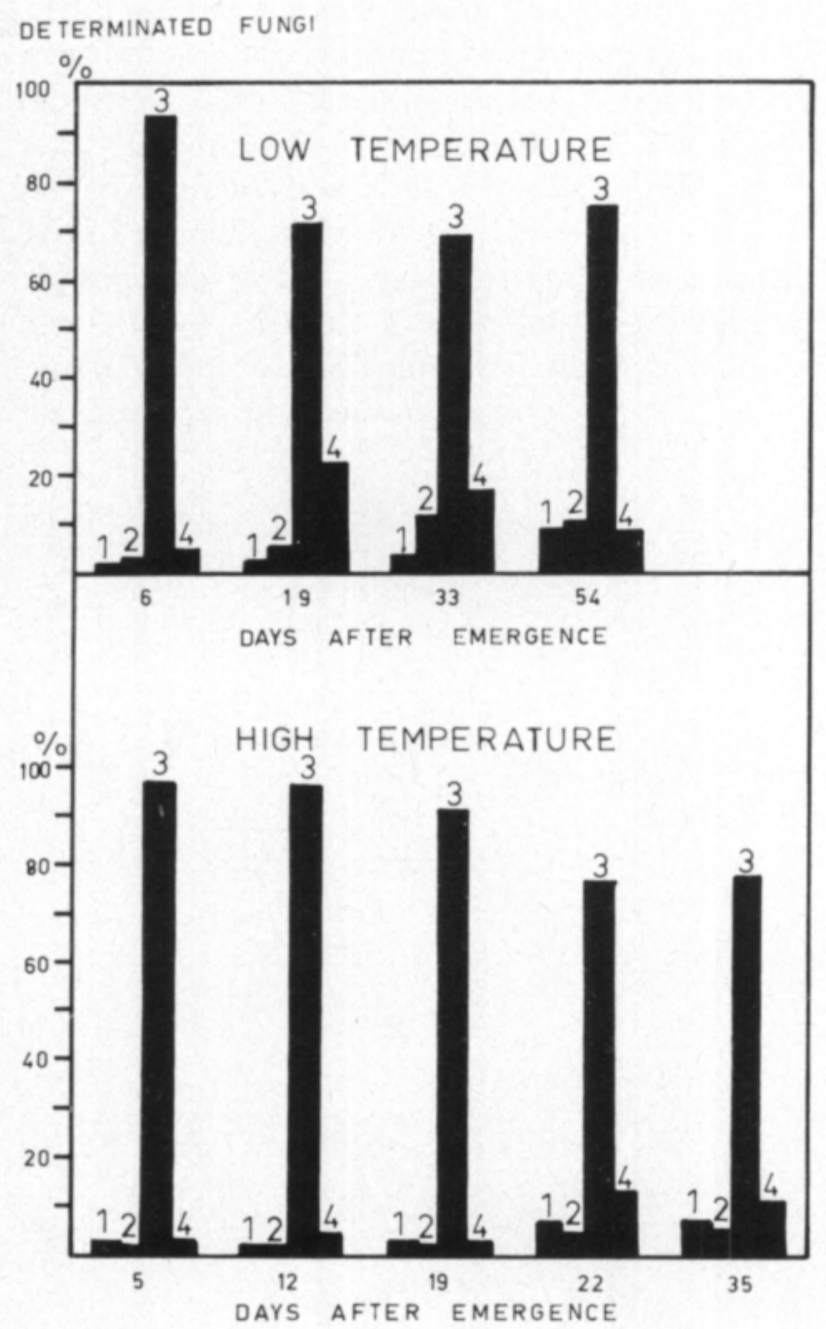

Fig. 7. The frequency of damping-off fungi isolated from soil samples at low and at high temperatures in a greenhouse, and at different times after emergence.

$1=$ FUSARIUM SPP

$2=$ PHOMA BETAE

$3=$ PYTHIUM DEBARYANUM

$4=$ OTHER DETERMINATED FUNGI 
agricultural proceedings. In the autumn at harvesting the abnormally developed beets can easily be separated from healthy beets (Fig. 6).

\section{Damping-off fungi}

The first isolations of damping-off fungi were made from sugar beet seedlings growing in the greenhouse. In this investigation out of the damping-off mycoflora of 48 soil samples Pythium debaryanum auct. non Hesse appeared to be the most common fungi (Fig. 7). The total number of fungual isolations made was 2309 belonging to 26 species. On an average, the $P$. debaryanum isolates constituted $87.3 \%$ of the total number of isolations made. Next to $P$. debaryanum, Fusarium spp. (2.8 \%), Phoma betae Frank $(2.2 \%)$ and Chaetonium globosum Kunze $(2.2 \%)$ were the most common fungi. $P$. debaryanum was isolated to a greater extent just after emergence

Table 1. The distribution of fungus species isolated from 35 soil samples at low $\left(+8-+10^{\circ} \mathrm{C}\right)$ and 48 soil samples at high $\left(+18-+20^{\circ} \mathrm{C}\right)$ temperatures in a green house.

\begin{tabular}{|c|c|c|c|}
\hline \multirow[b]{2}{*}{ Fungus } & \multicolumn{3}{|c|}{ Number of isolations } \\
\hline & $\begin{array}{c}\text { Low } \\
\text { temperature }\end{array}$ & $\begin{array}{c}\text { High } \\
\text { temperature }\end{array}$ & Together \\
\hline Acremoniella atra (Corda) Sacc. & 0 & 1 & 1 \\
\hline Acrostalagmus sp. & 1 & 0 & 1 \\
\hline Alternaria tenuis Nees & 2 & 8 & 10 \\
\hline Aspergillus niger van Thieg. & 0 & 1 & 1 \\
\hline Botrytis cinerea Pers. ex Fr. & 1 & 1 & 2 \\
\hline Cephalosporium sp & 0 & 4 & 4 \\
\hline Chaetomium globsum Kunze ex Fr. & 15 & 36 & 51 \\
\hline Cladosporium cladosporioides (Fres.) Sacc. & 2 & 0 & 2 \\
\hline Coniotyrium sp. & 1 & 0 & 1 \\
\hline Cylindrocarpon sp. & 16 & 11 & 27 \\
\hline Dendrophion nanum (Nees ex Fr.) Hughes & 0 & 1 & 1 \\
\hline Fusarium spp. & 14 & 50 & 64 \\
\hline Graphium sp. & 0 & 1 & 1 \\
\hline Humicola fuscoatra Traaen & 0 & 5 & 5 \\
\hline Mucor sp. & 0 & 3 & 3 \\
\hline Penicillium sp. & 1 & 8 & 9 \\
\hline Phoma betae Frank & 24 & 27 & 51 \\
\hline Phoma sp. & 1 & 19 & 20 \\
\hline Pythium debaryanum auct. non Hesse & 337 & 1678 & 2015 \\
\hline Rhizoctonia solani Kühn & 6 & 3 & 9 \\
\hline Rhizopus nigricans Ehrenb. & 1 & 0 & 1 \\
\hline Sordaria sp. & 2 & 0 & 2 \\
\hline Torula sp. & 4 & 10 & 14 \\
\hline Trichoderma viride Pers. ex Fr. & 0 & 1 & 1 \\
\hline Ulocladium consortiale (Thümen) Simmons & 6 & 5 & 11 \\
\hline Volutella sp. & 0 & 2 & 2 \\
\hline Together & 434 & 1875 & 2309 \\
\hline
\end{tabular}


Table 2. Emergence and damping-off of sugar beet at low $\left(+8-+10^{\circ} \mathrm{C}\right)$ and at high temperatures $\left(+18-+20^{\circ} \mathrm{C}\right)$ in a green house.

\begin{tabular}{llll}
$\begin{array}{l}\text { Temperature } \\
\text { in the green house }\end{array}$ & $\begin{array}{l}\text { Number of soil } \\
\text { samples in- } \\
\text { vestigated }\end{array}$ & $\begin{array}{c}\text { Emergence } \\
\%\end{array}$ & $\begin{array}{c}\text { Damping-off } \\
\%\end{array}$ \\
\hline$+8-+10^{\circ} \mathrm{C}$ & 35 & $63.3(17.5-88.9)$ & $26.7(4.8-72.7)$ \\
$+18-+20^{\circ} \mathrm{C}$ & $35+13$ & $78.8(20.6-95.6)$ & $54.18 .0-100.0)$ \\
\hline
\end{tabular}

Table 3. The distribution of fungus species isolated from seedling samples collected from sugar beet fields at about 10 and 20 days after emergence during 1979-1981.

Number of isolations

10 days after emergence 20 days after emergence

\begin{tabular}{|c|c|c|c|c|c|c|c|}
\hline & & & & & & & \\
\hline Fungus & 1979 & 1980 & 1981 & 1979 & 1980 & $1981 \mathrm{To}$ & gether \\
\hline Alternaria tenuis Nees & 27 & 45 & 15 & 17 & 123 & 5 & 232 \\
\hline Ascochyta sp. & 0 & 0 & 2 & 0 & 0 & 1 & \\
\hline Botrytis cinerea Pers. ex Fr. & 0 & 0 & 2 & 0 & 0 & 0 & \\
\hline Cephalosporium sp. & 0 & 0 & 7 & 0 & 0 & 0 & \\
\hline Chaetomium sp. & 2 & 0 & 2 & 7 & 3 & 1 & 15 \\
\hline Cladosporium cladosporioides (Fres.) Sacc. & 5 & 4 & 1 & 3 & 12 & 1 & 26 \\
\hline Fusarium avenaceum (Fr.) Sacc. & 1 & 3 & 1 & 7 & 9 & 8 & 29 \\
\hline F. culmorum (W.G. Sm.) Sacc. & 10 & 14 & 10 & 91 & 57 & 24 & 206 \\
\hline F. dimerum Penzig & 0 & 0 & 0 & 0 & 0 & 10 & 10 \\
\hline F. graminearum Schwabe & 0 & 0 & 0 & 0 & 0 & 3 & \\
\hline F. moniliforme Sheld. & 0 & 1 & 0 & 0 & 1 & 0 & \\
\hline F. oxysporum Schlecht. & 0 & 17 & 3 & 86 & 118 & 6 & 230 \\
\hline F. sambucinum Fuck. & 17 & 17 & 29 & 61 & 90 & 17 & 231 \\
\hline Fusarium sp. & 46 & 67 & 25 & 171 & 121 & 113 & 543 \\
\hline Helminthosporium biforme Mason \& Hughes & 0 & 0 & 0 & 1 & 0 & 0 & \\
\hline Humicola fuscoatra Traaen & 0 & 0 & 2 & 0 & 0 & 2 & \\
\hline Mucor spp. & 2 & 3 & 1 & 0 & 17 & 12 & 35 \\
\hline Olpidium sp. & 2 & 7 & 10 & 45 & 13 & 132 & 209 \\
\hline Papulaspora sp. & 0 & 0 & 0 & 0 & 2 & 0 & \\
\hline Penicillium sp. & 7 & 0 & 2 & 1 & 0 & 0 & 10 \\
\hline Phoma betae Frank & 18 & 12 & 3 & 36 & 20 & 14 & 103 \\
\hline Phoma sp. & 5 & 11 & 5 & 14 & 11 & 9 & 55 \\
\hline Pythium debaryanum auct. non Hesse & 408 & 487 & 428 & 398 & 160 & 106 & 1987 \\
\hline Pythium sp. & 0 & 0 & 0 & 7 & 0 & 4 & 11 \\
\hline Periconia sp. & 0 & 0 & 4 & 0 & 0 & 0 & \\
\hline Rhizoctonia solani $\mathrm{Kühn}$ & 0 & 0 & 0 & 3 & 0 & 0 & \\
\hline Rhizopus nigricans Ehrenb. & 0 & 0 & 1 & 1 & 0 & 0 & \\
\hline Sordaria sp. & 3 & 0 & 6 & 8 & 0 & 1 & 18 \\
\hline Torula sp. & 3 & 7 & 0 & 1 & 0 & 2 & 13 \\
\hline Trichocladium asperum $\mathrm{Harz}$ & 0 & 0 & 0 & 0 & 0 & 1 & 1 \\
\hline Trichoderma viride Pers. ex Fr. & 2 & 0 & 0 & 1 & 0 & 0 & \\
\hline Ulocladium consortiale (Thümen) Simmons & 11 & 16 & 34 & 133 & 19 & 26 & 239 \\
\hline Together & 569 & 711 & 593 & 1092 & 776 & 498 & 239 \\
\hline
\end{tabular}


Fig. 8. The frequency of damping-off fungi isolated from field samples at about 10 and 20 days after emergence in 1979-1981.

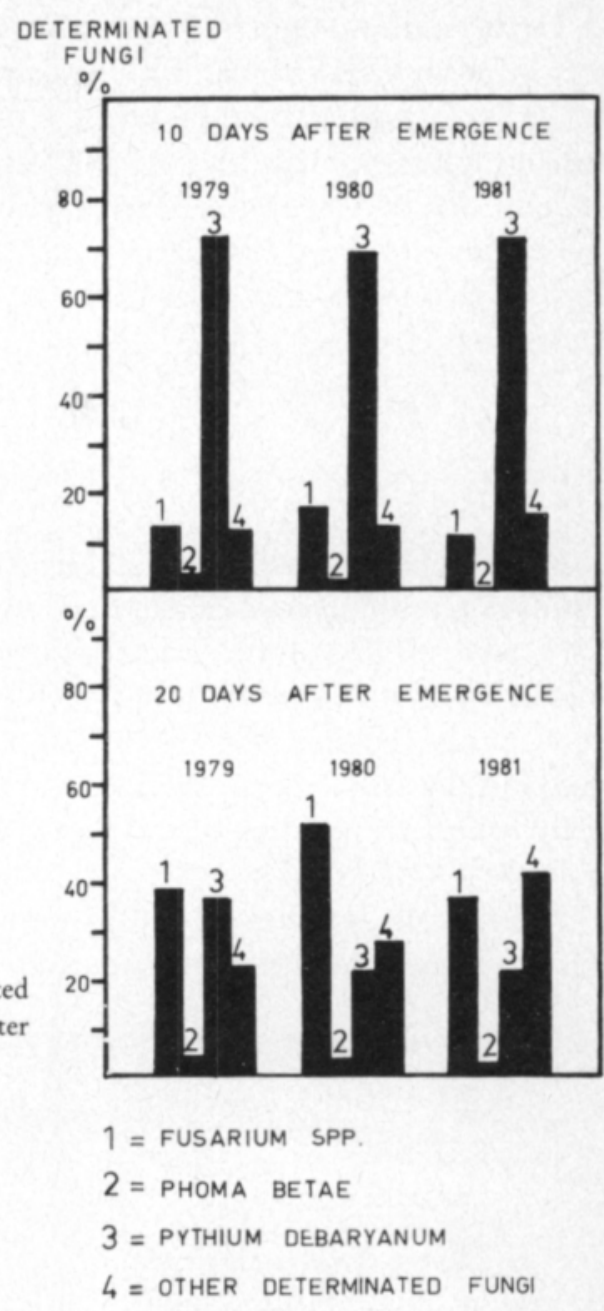

than at later seedling stages (Fig. 7). The amount of the fungus was $95.6 \% 5$ days after emergence in comparison with $77.6 \% 35$ days after emergence. With Phoma betae and Fusarium spp. the case was in this respect the reverse. Temperature had no clear affect on the relationships between the pathogens (Fig. 7, Table 1). Damping-off occurred to a significantly higher degree at high temperatures than at low, but emergence was poorer at low than at high temperatures (Table 2). This presumably was due to a greater pre-emergence damping-off at the lower temperature.

The total number of fungus isolations from sugar beet seedlings growing in the field during 1979-1981 was more than 4000 (Table 3). Here, just as in the soil sample investigation, the fungus $P$. debaryanum proved to be the most common fungus, especially at the earliest seedling stage (Fig. 8). The procentual number of $P$. debaryanum at the early seedling stage was in $197971.7 \%$ and at a later seedling stage $36.4 \%$. The corresponding values for 1980 and 1981 were $68.5 \%, 20.6 \%$ and $72.2 \%, 21.1 \%$ respectively. Fungi belonging to the genus Fusarium occurred more commonly at later seedling stages than 
at early seedling stages. $P$. betae was isolated to a rather small extent from seedlings attacked by damping-off under field conditions. The number of $P$. betae isolations varied between $0.5 \%$ and $3.3 \%$ according to locality, collecting time of the samples and year. The occurrence of the fungus did not depend on the stage of seedling development. Alternaria tenuis Nees occurred rather commonly in 1980, Ulocladium consortiale (Thüm) Simm. in 1979 and Olpidium sp. in 1981 (Table 3), but the pathogenicity of these fungi is questionable.

\section{Pythium debaryanum auct. non Hesse}

The genus Pythium was established by Pringsheim, who placed it in the family Saprolegniaceae. Since that time many taxonomic details of the genus have been studied and characteristics for new species described. The relationship with other Oomycetes has been established and the genus was put into a new family, Pythiaceae, in 1897 (HENDRIX and CAMPBELL 1973). During this century valuable supplements to the botanical position of the genus have been found by among others MATTHEWS (1931), MIDDLETON (1943) and WATERHOUSE (1967).

The fungus survives in soil by resting spores and by saprophytic growth. Pythium spp. do not compete well with other micro-organisms and they
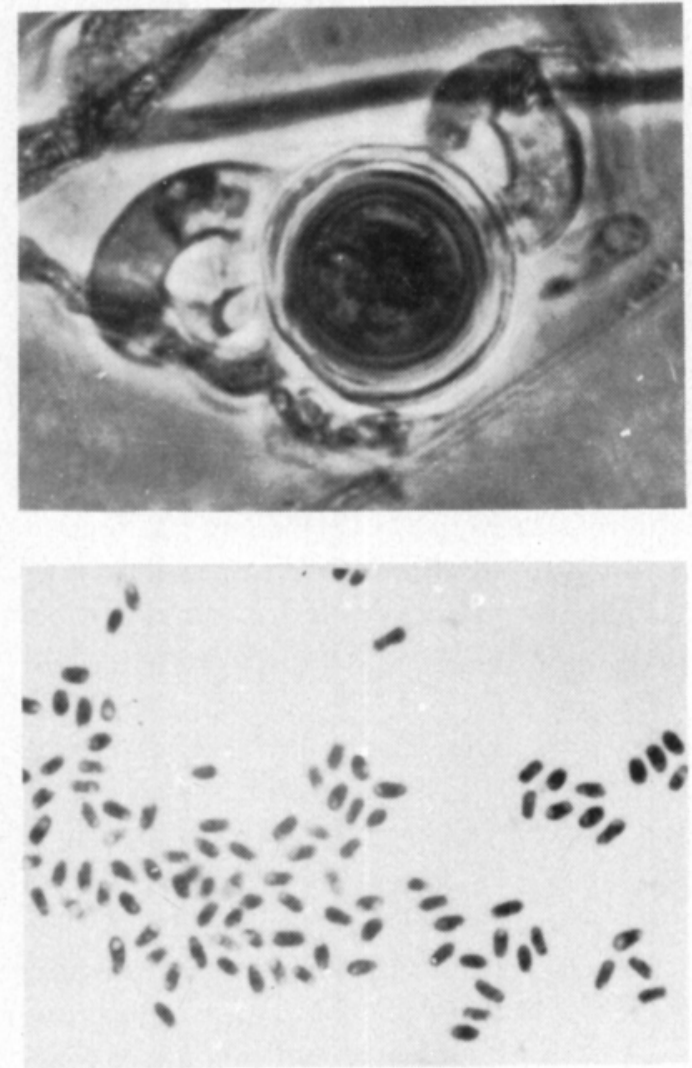

Fig. 9. Pythium debaryanum. Oogonium and antheridia. $\times 1500$.

Fig. 10. The pycnospores of Phoma betae. $\times 1200$. 
grow saprophytically only under circumstances where other organisms are not present or have reduced growth due to unfavourable conditions in the soil. However, survival by resting structures is more important than survival by saprophytic growth. As the case is with many other soil fungi, the mycelium of Pythium spp. undergoes lysis in lack of suitable nutrient sources or when the sources are colonized by competiting micro-organisms. The main mechanism of survival for short and intermediate periods is by zoospores and sporangia and by oospores for long periods (HENDRIX and CAMPBELL 1973).

The Pythium species found in this investigation has, according to WATERHOUSE (1967) been determined as $P$. debaryanum auct. non Hesse. The fungus grew rapidly on CMA- or PDA-substrate covering the surface of the agar in petri dishes $(\varnothing 9 \mathrm{~cm})$ after about two days. The aerial mycelium was hyaline, unseptate, single hyphae up to $10 \mu \mathrm{m}$ wide. The formation of oogonia was abundant on CMA substrate, especially when adding wheat germ oil to the substrate. The oogonia were globose, terminal or intercalary and $25.3 \mu \mathrm{m}(20-32 \mu \mathrm{m})$ in diameter. Oospores were $20.2 \mu \mathrm{m}(15-24 \mu \mathrm{m})$ in diameter, smooth and apleurotic. There were up to $5(1-5)$ antheridia, usually $2-3$ from the same or from another hypha than the oogonium. They were clubshaped, with a long stalk and 6-10 $\mu \mathrm{m}$ in diameter (Fig. 9). Sporangia formed only in one case. They were sphaerical to oval, $20-28 \mu \mathrm{m}$ in diameter.

\section{Phoma betae Frank}

The first observations of $P$. betae as a causal agent of damping-off on sugar beet were made by FRANK (1894). The morphology of the fungus has been described by EDSON (1915) and especially by BJÖRLING (1945), who also described the sexual form of the fungus, Pleospora betae.

$P$. betae is a seed borne fungus and the main mechanism for survival over longer periods is in the seed. The ability of the fungus to survive in the soil or in plant residues in the soil is questionable varying from a few months to two years (POOL and MC KAY 1915, BUGBEE and SOINE 1974). According to MC KAY (1952) $P$. betae cannot survive in soil without suitable plant residues.

$P$. betae grew well on CMA-substrate. The mycelium of the fungus did not show as rapid a growth as that of $P$. debaryanum. Young hyphae were hyaline, septate, becoming brownish at older stages, $2-10 \mu \mathrm{m}$ in width. Different isolates of the fungus formed varying amounts of pycnidia. The pycnospores were sphaerical to rodshaped, hyaline, 3-5 $\mu \mathrm{m}$ long and about $2 \mu \mathrm{m}$ wide (Fig. 10).

\section{Pathogenicity of the fungi}

The first pathogenicity test with 6 fungus species isolated from sugar beet seedling in 1980 shows that only Pythium debaryanum and Phoma betae are 


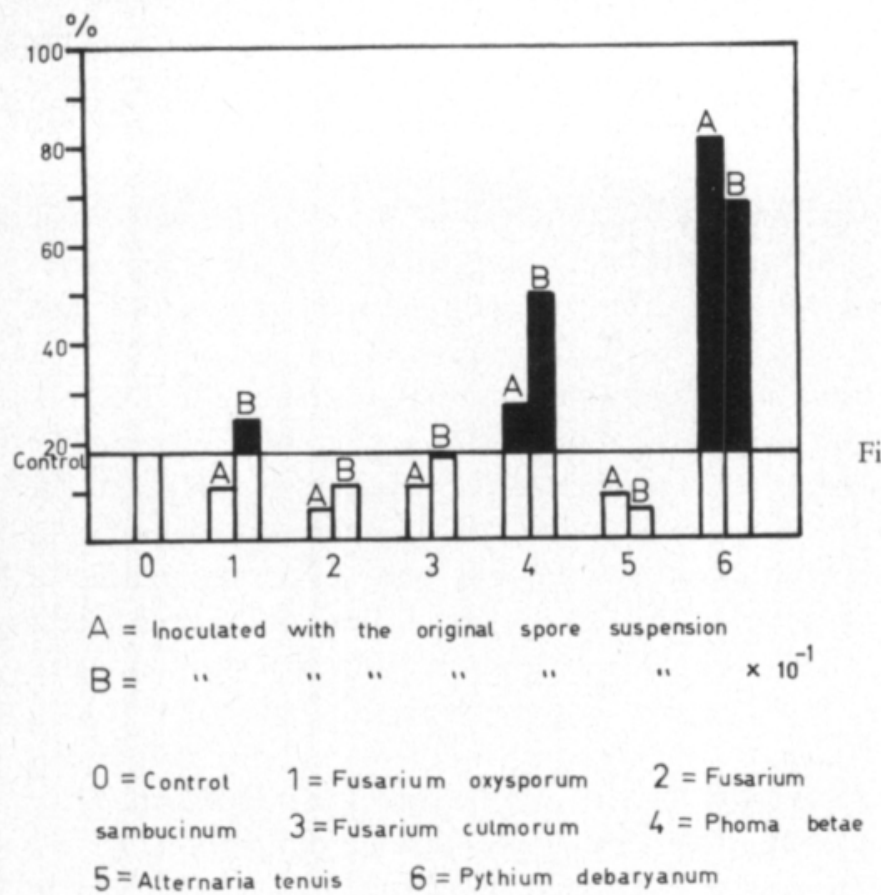

Fig. 11. The pathogenicity of some damping-off fungi to sugar beet seedlings.

capable of causing damping-off on sugar beet when inoculated into peat. In this experiment, a tenfold dilution of the original spore suspensions was made and this led to a more serious infection when inoculating with $P$. betae, but with $P$. debaryanum the dilution had no significant effect (Fig. 11).

The pathogenicity of 12 isolates of $P$. debaryanum and of 5 isolates of $P$. betae was tested. The results show that there were differencies between the isolates in this respect (Fig. 12). Compared with the control all but nr. 3 and 11 of the Pythium isolates were pathogenic, the most highly pathogenic being nr. 4, 5 and 12. In this experiment a ten- or hundredfold dilution of the basic spore suspension led to a rapid decrease in the disease causing ability. Out of the five isolates of $P$. betae examined, only one did not cause disease. Tenand hundredfold dilutions of $P$. betae still gave rise to damping-off, which is in contrast to the corresponding results of $P$. debaryanum.

$P$. debaryanum attacked the plants faster than P. betae (Fig. 13). Two days after emergence $11 \%$ of the plants growing in pots inoculated with $P$. debaryanum showed signs of damping-off, when the corresponding number in $P$. betae was only $1.5 \%$. This difference, however, was soon equalized in such a way that both treatments showed the same amount of disease at the end of the experiment.

Fig. 12. The pathogenicity of different Pythium debaryanum and Phoma betae isolates to sugar beet seedlings. 
DAMPING - OFF

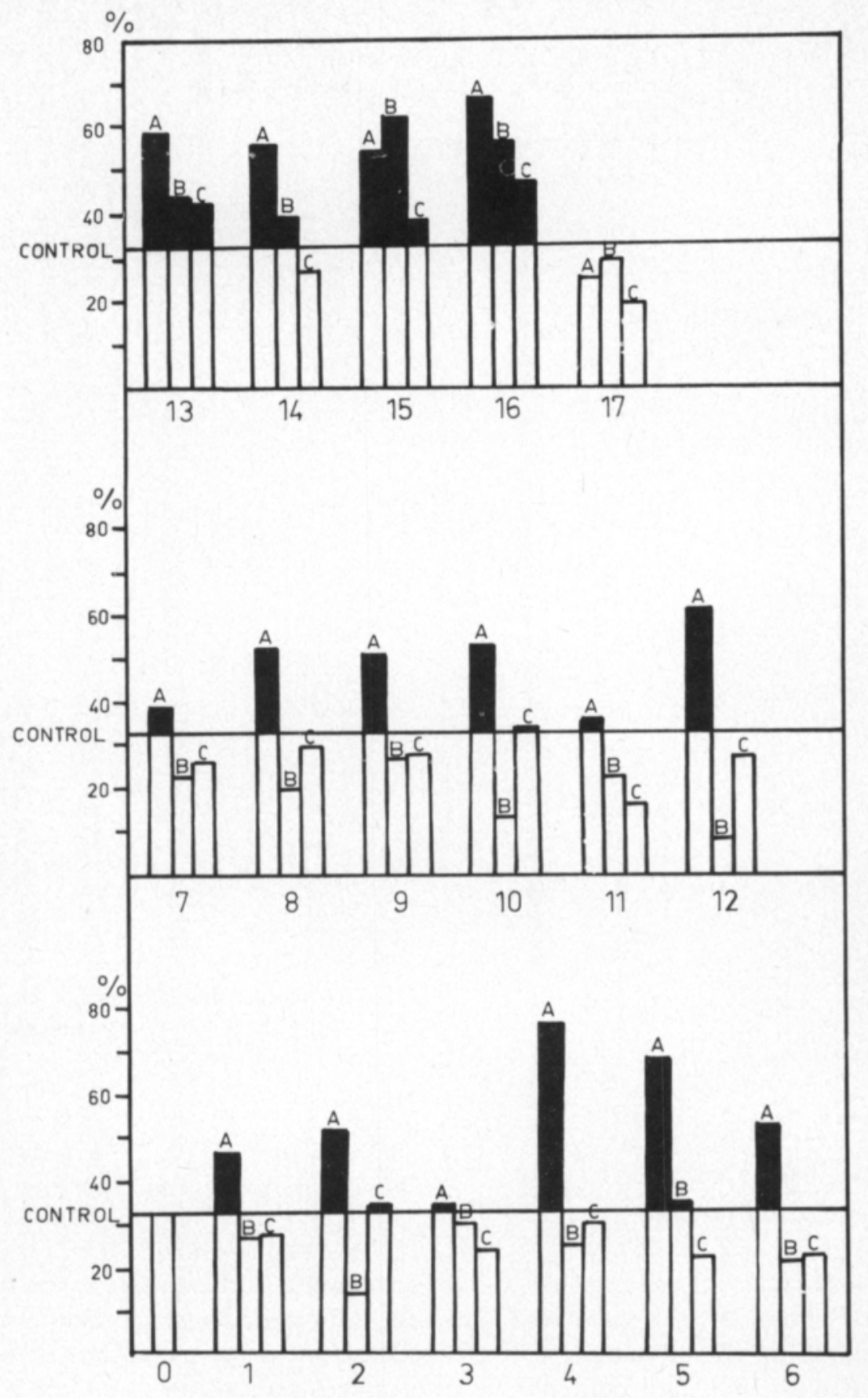

$A=$ Inoculated with the original spore suspension

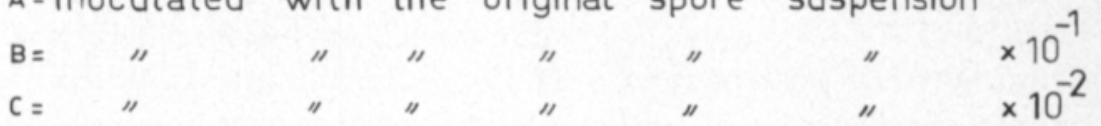

$0=$ Control $1-12=$ Isolates of Pythium debaryanum $13-17=$ Isolates of Phoma betae 


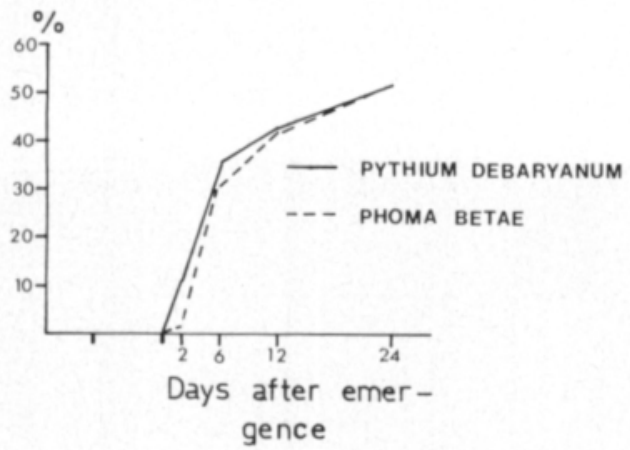

Fig. 13. Rates at which Pythium debaryanum and Phoma betae attack sugar beet seedlings when inoculated into peat.
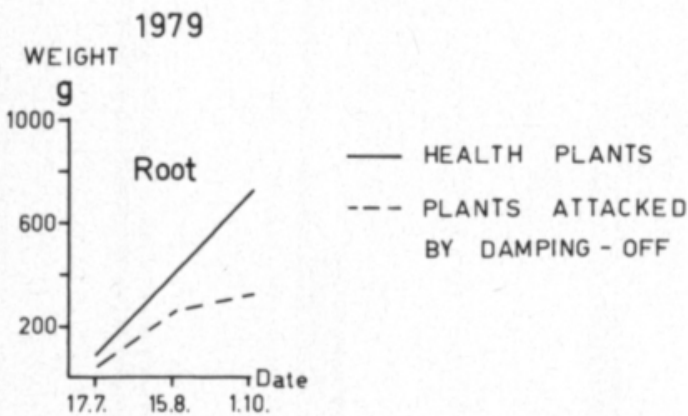

1980
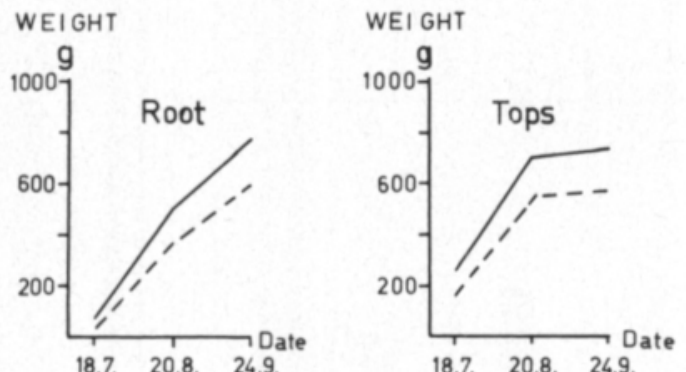

Fig. 14. Quantitative development of the roots and tops of beets with damping-off and healthy beets.

\section{Disease and soil factors}

The occurrence of damping-off and the correlation of the disease to the soil type, $\mathrm{pH}$-number and some soil minerals important to sugar beet were investigated in 47 soil samples. The percentage of damping-off varied between 8 and 100. The contents of phosphorus, potassium, sodium and magnesium also varied to some degree. The content of humus was on an average $9.9 \%(1.7-44.3)$ and the $\mathrm{pH}$-number 6.2. (5.1-6.9). There was no correlation between postemergence damping-off and any of the soil factors measured. However, when both pre- and postemergence damping-off were taken into regard there were weak negative correlations between the amount of damping-off and the content of potassium, sodium or magnesium (Table 4). 
Table 4. Correlations between damping-off and some soil qualities 47 soil samples. Temperature in a green house $+18-+20^{\circ} \mathrm{C}$.

\begin{tabular}{|c|c|c|c|c|}
\hline & & & \multicolumn{2}{|c|}{ Correlation to damping-off } \\
\hline \multicolumn{3}{|c|}{ Soil } & $\begin{array}{c}\text { Pre- + postemer- } \\
\text { gence } \\
\text { damping-off }\end{array}$ & $\begin{array}{c}\text { Postemergence } \\
\text { damping-off }\end{array}$ \\
\hline Quality & & Value & $\mathrm{r}$ & $\mathrm{r}$ \\
\hline Humus, $\%$ & & $9.9(1.7-44.3)$ & -0.095 & -0.043 \\
\hline Clay, \% & & $20.3(2-73)$ & -0.065 & -0.058 \\
\hline $\mathrm{pH}_{\mathrm{CaCl}_{2}}$ & & $6.2(5.1-6.9)$ & -0.007 & 0.078 \\
\hline Phosphorus, & $\mathrm{mg} / \mathrm{l}$ soil & $51(15-141)$ & -0.098 & -0.069 \\
\hline Potassium, & $" \quad n$ & $264(84-465)$ & $-0.256^{x}$ & 0.071 \\
\hline Sodium, & $n \quad n$ & $34(10-112)$ & $-0.298^{\mathrm{xx}}$ & -0.118 \\
\hline Magnesium, & $n \quad "$ & $217(48-770)$ & $-0.271^{x}$ & -0.158 \\
\hline
\end{tabular}

Table 5. The quality properties of diseased beets in relation to healthy beets just before harvest at the end of September in 1979 and in 1980.

\begin{tabular}{|c|c|c|c|c|c|c|c|c|c|}
\hline \multirow{3}{*}{$\begin{array}{l}\text { Locality } \\
\text { Viikki Experimental } \\
\text { Farm, Helsinki }\end{array}$} & \multirow{3}{*}{$\begin{array}{l}\text { Year } \\
1979\end{array}$} & \multirow{2}{*}{\multicolumn{2}{|c|}{$\begin{array}{l}\frac{\text { Sugar content }}{\%} \\
\text { healthy diseased }\end{array}$}} & \multirow{2}{*}{\multicolumn{2}{|c|}{$\begin{array}{l}\frac{\text { Amino- } \mathrm{N}}{\mathrm{mg} / 100 \mathrm{~g} \text { beets }} \\
\text { healthy diseased }\end{array}$}} & \multirow{2}{*}{\multicolumn{2}{|c|}{$\begin{array}{l}\text { Potassium } \\
\mathrm{mg} / 100 \mathrm{~g} \text { beets } \\
\text { healthy diseased }\end{array}$}} & \multirow{2}{*}{\multicolumn{2}{|c|}{ 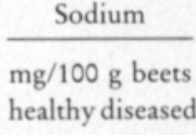 }} \\
\hline & & & & & & & & & \\
\hline & & 15.6 & 15.9 & 37 & 41 & 9.3 & 9.7 & 0.7 & 0.8 \\
\hline Porvoon maalaiskunta & $"$ & 15.4 & 14.5 & 46 & 63 & 8.1 & 7.5 & 1.5 & 1.4 \\
\hline $\begin{array}{l}\text { Viikki Experimental } \\
\text { Farm, Helsinki }\end{array}$ & 1980 & 15.2 & 15.1 & 38 & 33 & 9.8 & 9.3 & 0.8 & 0.7 \\
\hline Mietoinen & $"$ & 17.2 & 16.4 & 36 & 30 & 6.9 & 7.2 & 0.4 & 0.4 \\
\hline Salo & $"$ & 15.6 & 15.7 & 27 & 42 & 6.9 & 7.0 & 1.1 & 1.0 \\
\hline Janakkala & $"$ & 15.8 & 15.8 & 38 & 42 & 8.7 & 8.8 & 0.6 & 0.5 \\
\hline Köyliö & $"$ & 15.1 & 15.9 & 33 & 35 & 7.9 & 8.5 & 0.7 & 0.5 \\
\hline Average & & 15.7 & 15.6 & 36 & 41 & 8.2 & 8.3 & 0.8 & 0.8 \\
\hline
\end{tabular}

\section{Effect of damping-off on the quantitative and qualitative development of beet plants}

When comparing the quantitative development of beet plants attacked by damping-off but surviving, to that of healthy plants, it is evident that they develop at a different rate than the healthy plants (Fig. 14). In the middle of July 1979 , the root weight of the diseased plants was only $47 \%$ of the healthy ones. The corresponding value for 1980 was $50 \%$. In the middle of August the root weights were 63 and $77 \%$ respectively. In September, just before harvest the infected beets had a root weight of $44 \%$ in 1979 and in $198077 \%$ of the healthy ones. The development of the top weights followed a pattern similar to that of the root weight (Fig. 14). 
In September 1979 and 1980 some quality factors of the beet roots were also determined. The average results from two years investigations show that the disease only slightly influenced the content of sugar, potassium and sodium, but that the content of amino- $\mathrm{N}$ compounds was higher in diseased plants than in healthy plants (Table 5). However, in localities with very serious attacks opf damping-off, as in Porvoo in 1979, the disease also leads to a lower sugar content in the beet roots.

\section{Discussion}

The fungus Pythium debaryanum auct. non Hesse occurs widely in Finnish sugar beet fields, and is by far the most important causal agent of damping-off on sugar beet in Finland. Evidence of this is available from a soil sample investigation, field investigations and pathogenicity tests. These results are in agreement with several other works (among others BUCHHOLTZ 1938, KÜHNEL 1978). P. debaryanum seems to have a very quick mode of action, attacking the sugar beet seedlings mainly within two weeks after emergence, under certain conditions even before emergence. The outbreak of disease at this early stage leads almost always to the death of the seedlings. When the attack takes place later, many of the affected plants may continue to live and are invaded by secondary pathogens and saprophytic fungi. $P$. debaryanum being a weak competitor with these (HENDRIX and CAMPBELL 1973) is no longer commonly found in 3-5 weeks old seedlings. To get a correct picture of the causal agents of the disease one must therefore collect samples at short intervals beginning from the emergence.

Globally the fungus Phoma betae Frank is somewhat as common as Pythium spp. on beet (DUNNING 1971), but in this investigation the fungus played no important role. However, 25 years ago $P$. betae was as common as $P$. debaryanum in Finland (LINNASALMI 1970). Because P. betae is a seed borne beet pathogen, the reason for its decline as a causal agent of dampingoff must be that the seeds nowadays are quite clean from infection. Overwintering of the fungus in plant residues in the soil under Finnish conditions has not been investigated.

Another organism, Fusarium spp., was isolated quite commonly from beet samples collected at later seedling stages. According to GATES and HULL (1954) Fusarium spp. may be weak damping-off pathogens in acid soils with $\mathrm{pH}$-numbers lower than 6.5. In this investigation the pathogenicity of only one isolate of $F$. culmorum, $F$. oxysporum and $F$. sambucinum was studied. These isolates did not cause disease when inoculated into peat. However, knowing the great variation within the genus Fusarium and among isolates within different Fusarium species, and that the peat substrate is not the most suitable one for sugar beet, it is difficult to draw any conclusions about the real pathogenicity of the fungus. On the whole, the actual role of Fusarium spp. in the damping-off complex of sugar beet needs further investigations.

On the basis of field and greenhouse observations the damping-off disease of sugar beet can in Finland be divided into two distinct types, which are very 
similar to those described by WARREN (1948). Firstly, a very dangerous type which rapidly results in the death of the plants. This phase begins with the germination of the seed and continues to the time, when the first true leaves develop. Secondly, a cronic type which begins after the first phase and continues for some weeks. The later stage of this type of damping-off has often been given the name "strangles" (BOYD 1966, SCHOLLMEYER 1980) and has been said to be mainly due top abiotic factors. However, under Finnish conditions, it seems clear that the symptoms referred to as "strangles" have their origin in typical damping-off symptoms, which are caused by different micro-organisms.

In this investigation no correlation between damping-off and the $\mathrm{pH}$ number or the amount of humus and clay in the soil was found. Concerning the $\mathrm{pH}$-number these results differ from many other works (BUCHHOLTZ 1938, MC KAY 1952), in which a rise of the $\mathrm{pH}$-number has led to a decrease in the disease. In this investigation there were no soils with the $\mathrm{pH}$-number over 7, possibly explaining the lack of response. The importance of the soil type for the occurrence of damping-off is contradictory (GATES and HULL 1954, REMY 1950). According to many works the physical qualities of the soil are more important than the soil type (GRAM 1927, COONS and STEWART 1927, LIKAIS 1948). The weak preventive effect of potassium, sodium and magnesium, that was found in this study, is in agreement with the works of YALE and VAUGHAN (1962). In some other studies especially the application of phosphorus prevents the disease (MÖLLERSTRÖM and KLINTEBERG 1964).

Already in 1945 BJÖRLING suggested, that beet plants recovering from the attack of damping-off, develop into beets, which are quantitatively and qualitatively inferior to healthy beets. In the present study the correctness of this statement was justified. But it was also seen that recovering is very much dependent on the weather conditions of the year. In 1980, when the summer was warm and precipitation sufficient, the plants recovered better than in 1979.

Acknowledgements and participation. The results of this study were produced with the co-operation of the Department of Plant Pathology at the Helsinki University and the Finnish Sugar Beet Research Centre. Dr. Agr. and For. Risto Tahvonen and Lic. Agr. and For. Mauritz Vestberg from the Department of Plant Pathology have been responsible for the mycological experiments. Dr. Agr. and For. Kyösti Raininko and Agr. Nils Nuormala have, on behalf of the Sugar Beet Research Centre, participated in the planning of the experiments and have been responsible for the practical side of establishing and conducting the field experiments.

The Finnish Foundation for Sugar Beet Cultivation and the Finnish Association of Academic Agronomists have supplied Mauritz Vestberg with a grant to help promote the study. Agricultural experts and agronomists from different sugar factories have helped establish and complete the experiments and a number of farmers gave their fields to be used for the experiments. The head of the Department of Plant Pathology Prof. Eeva Tapio has, by her encouragement and support made it possible for the completion of the experiment. We would like to express our warmest thanks to all the above. 


\section{References}

BJÖRLING, K. 1945. Undersökningar rörande Phoma betae (Oud.) Fr. med särskild hänsyn till en av svampen orsakad stjälkröta på betfröplantor. Stat. Växtskyddsanst. Medd. 44: 1-96.

BOYD, A. E. W. 1966. Sugar beet strangles. Edin. School. Agric. Tech. Bull. 26, 42 p.

BUCHHOLTZ, W. F. 1938. Factors influencing the pathogenicity of Pythium debaryanym on sugar beet seedlings. Phytopath. 28: 448-475.

BUGBEE, W. M. \& SOINE, O. C. 1974. Survival of Phoma betae in soil. Phytopath. 64: 1258-1260.

BÖTTCHER, I. \& BEHR, L. 1980. Pilze der Gattung Pythium als Wurzelbranderreger der Zuckerrübe. Arch. Phytopath. u. Pfl. schutz 16: 95-102.

COONS, G. H., KOTILA, J. E. \& BOCKSTAHLER, H. W. 1946. Black root of sugar bets and possibilities for its control. Proc. Am. Soc. Sugar Beet Technol. 1946: 364-380.

COONS, G. H. \& STEWART, D. 1927. Prevention of seedling diseases of sugar beets. Phytopath. 17: 259-296.

DUNNING, R. A. 1971. Sugar beet pest and disease incidence and damage, and pesticide usage. Report of an I.I.R.B. enquiry. J. Intern. Inst. Sugar Beet Res. 6: 19-34.

EDSON, H. A. 1915. Seedling disease of sugar-beets and their relation to root-rot and crown-rot. J. Agric. Res. 4. (Ref. NÖLlE 1960).

FRANK, A. B. 1892. Ueber Phoma betae, einen neuen parasitischen Pilz, welcher die Zuckerrüben zerstört. Z. Rüben und Indus. 42 (Ref. BJÖRLING 1945).

GATES, L. F. \& HULL, R. 1954. Experiments on black leg disease of sugarbeet seedlings. Ann. Appl. Biol. 41: 541-561.

GERHOLD, N. R. 1956. Sugar beet diseases and their control. Abs. in Iowa st. Coll. J. Sci. 30: 362 (Ref. R. A. M. 36: 156).

GREIS, H. 1942. Soll Rübensamen gebeizt werden? Z. Wirtschaftsgruppe Zuckerind. 92: 2-46, 85-113. (Ref. NÖLLE 1960).

HENDRIX, F. F. \& CAMPBELL, W. A. 1973. Pythiums as plant pathogens. Ann. Rev. Phytopath. 11: 77-98.

HILLS, F. J. \& LEACH, L. D. 1952. The effect of certain soil-row treatments on damping-off of sugar beet seedlings caused by specific fungi. Proc Am. Soc. Sugar Beet Technol. 1952: 549-553.

HODGES, F. A. 1936. Fungi of sugar beets. Phytopath. 26: 550-563.

KÜHNEL, W. 1978. Untersuchungen zur Verbreitung bodenbürtigen Wurzelbranderreger der Zuckerrübe. Arch. Phytopath. u. Pfl. schutz 14: 109-114.

LEACH, L. D. 1941. Seedling diseases of sugar beet. Sug. beet Bull. 5.

LIKAIS, R. 1948. Einfluss des Bodens und antagonistischer Bodenmikroben auf der Parasitismus von Pythium debaryanum. Arch. Mikrobiol. 18: 49-100.

LINNASALMI, A. 1970. Sokerijuurikkaan taimipolte ja sen torjunta Suomessa. Ann. Agr. Fenn. 9: 296-303.

MATTHEWS, V. D. 1931. Studies on the genus Pythium. University of N. C. Press. Chapel Hill. 136 p. (Ref. HENDRIX \& CAMPBELL 1973).

MC KAY, R. 1952. Sugar beet diseases in Ireland. Irish Sugar company LTD. 77 p. Dublin.

MIDDLETON, J. T. 1943. The taxonomy, host range and geographic distribution of the genus Pythium. Mem. Torrey Bot Club 20: 1-171.

MÖLLERSTRÖM, G. 1974. Odlingsteknik och pesticidanvändning inom sockerbetsodlingen. Stat. Växtskyddsanst. Medd. 160: 1-50.

— \& KLINTEBERG, H. B. 1964. Black leg in sugarbeets. Socker Handl. II 19: 1-15.

NÖLLE, H.-H. 1960. Über den Wurzelbrand der Zuckerrübe und seine Bekämpfung. Phytopath. Z. 37: $161-200$,

PAPAVIZAS, G. C. \& AYERS, W. A. 1976. Aphanomyces species and their root diseases in pea and sugar beet. A review. Agricultural Research Service. U.S. Dep. of Agric. Tech. Bull. 1485.158p. Washington DC.

PESHEL. R. 1969. Das Auftreten der wichtigsten Krankheiten und Schädlinge der landwirtsschaftliche und gärtnerischen Kulturpflanzen im Jahre 1968 im Bereich der Deutschen Demokratischen Republik. Nachr.bl. dt. Pfl.schutzd. 23: 141-170.

POOL, V. W. \& MC KAY, M. B. 1915. Phoma betae on the leaves of sugar beet. J.Agric. Res. 4: $169-177$. 
RASMUSSEN, A. N. 1967. Afsvampning av bederoefrø. Tidsskr. Planteavl. 71: 345-354.

REMY, E. 1950. Über niedere Bodenphycomyceten. Arch. Mikrobiol. 14: 212-239.

SCHOLLMEYER, M.-L. 1980, "Strangles" -eine im Jahre 1979 aufgetretene Erkrankung an Zuckerrüben. Nachr. bl. für den Pfl. schutz in der DDR 34: 252-253.

SCHULTZE, E. \& BOHLE, H. 1976. Zuckerrübenproduktion. Landwirtsschaftliche Bodennutzung mit hoher Rendite. 266 p. Berlin und Hamburg.

WARREN, J. 1948. A study of the sugar beet seedling disease in Ohio. Phytopath. 38: 883-892.

WATERHOUSE, G. M. 1967. Key top Pythium Pringsheim. Commonw. Mycol. Inst. Mycol. Papers 109. 15 p. Kew.

YALE, J. \& VAUGHAN, E. 1962. Effects of mineral fertilizers on damping-off of table beets. Phytopath. 52: $1285-1287$.

Ms received May 31, 1982

\title{
Sokerijuurikkaan taimipolte Suomessa. I. Taudinaiheuttajat ja eräi- den ulkoisten tekijöiden vaikutus taudin runsauteen.
}

\author{
Mauritz Vestberg*, Risto Tahvonen*, Kyösti Raininko*\% ja Nils \\ Nuormala*\%
}

\author{
* Helsingin yliopiston kasvipatologian laitos, 00710 Helsinki 71 \\ ** Sokerijuurikkaan tutkimuskeskus, 25170 Kotalato
}

Vuosina 1978-81 tutkittiin Helsingin yliopiston kasvipatologian laitoksen ja sokerijuurikkaan tutkimuskeskuksen välisenä yhteistyönä sokerijuurikkaan taimipoltteen aiheuttajia, taudin runsauteen vaikuttavia tekijöitä ja torjuntaa. Taimipolte on ollut useilla paikoilla eräs pahimmista ongelmista sokerijuurikkaan viljelyssä, mistä syystä laajemmat taimipoltetutkimukset katsottiin hyvin tarpeellisiksi. Tässä selostuksessa käsitellään taudin oireita, aiheuttajia ja niiden esiintymistä.

Vuonna 1978 kasvukauden päätyttyä kerättiin sokerijuurikaspelloilta 48 maanäytettä, joissa tehtyjen taimikasvatusten perusteella valittiin seuraaviksi vuosiksi kokeisiin mahdollisimman voimakkaasti saastuneet pellot. Astia- ja kenttäkokeista saaduista sairaista taimista eristettiin niissä olevat sienet, joista tärkeimpien patogeenisuudet testattiin. Sairaiden mutta henkiin jääneiden taimien kehitystä seurattiin sadon valmistumiseen asti.

Sokerijuurikkaan sirkkataimissa näkyivät ensimmäiset oireet $1-1.5$ viikkoa taimettumisen jälkeen. Sirkkavarsi vetistyi ja mustui. Lopuksi sirkkalehdetkin mustuivat ja taimet kuolivat. suotuisissa olosuhteissa sirkkataimet tuhoutuivat 1-2 päivässä. Kun sokerijuurikkaan taimet sairastuivat 1-2 lehtipariasteella, oireiden ilmaantuminen saattoi kestää päiviä ja kasvit jäivät useissa tapauksissa henkiin, jolloin juuri saattoi olla musta ja langan ohut. Sairaat mutta henkiin jääneet taimet katkeilivat helposti harvennuksessa ja harauksissa. Tällaisten kasvien juuret jäivät 33-47 \% :a terveitä kevyemmiksi ja nïssä voitiin usein nähdä tumma kuroutunut tai "kuristunut" vyö, josta kohdin juurikas saattoi vielä katketa sadonkorjuussa. Sairaissa juurikkaissa oli korkeampi amino-N-pitoisuus ja alhaisempi sokeri-\% kuin terveissä juurikkaissa.

Pythium debarynyanum auct. non Hesse oli taimipoltteen varhaisvaiheessa 70-90 \% :ssa ja kasvulehtiasteella 20-40 \% :ssa kasveista. Phoma betae Frank -sientä oli $0.5-3.3 \%$ :ssa. Fusarium -sieniä oli runsaasti taimipoltteen myöhäisemmässä kehitysvaiheessa, mutta ne eivät aiheuttaneet tuhoa yksinään patogeenisuuskokeissa. Niiden todellinen merkitys selviää kui- 
tenkin vasta lisätutkimusten jälkeen. Pythium- ja Phoma-sieni sitävastoin tappoi sokerijuurikkaan taimia voimakkaasti patogeenisuustesteissä.

Taimipoltetta esiintyi enemmän korkeassa $\left(18-20^{\circ} \mathrm{C}\right)$ kuin alhaisessa $\left(8-10^{\circ} \mathrm{C}\right)$ lämpötilassa, jossa oli kuitenkin huonompi taimettuminen. Taimipoltetta näytti esiintyvän pelloilla erityisen runsaasti, kun sirkkataimivaihe ajoittui kuumaan hellekauteen. Taimipoltteisuuden ja maan $\mathrm{pH}: \mathrm{n}$, humuspitoisuuden sekä lajitekoostumuksen välillä ei ollut rïppuvuutta. Kokonaistaimipoltteen (maa-alainen + maanpäällinen) ja maan kalium-, natrium- sekä magnesiumpitoisuuksien välillä oli heikko negatiivinen korrelaatio. 